\title{
U-SHAPE NONLINEARITY OF OWNERSHIP CONCENTRATION ON FIRM VALUE
}

\author{
Ahmad Aziz Putra Pratama, Universitas Airlangga \\ ahmad.aziz.putra-2018@feb.unair.ac.id
}

\begin{abstract}
The ownership and value relationship of the company has a lot of contentious issues. Previous studies have only examined the linear effect of ownership concentration on company value. In contrast to previous studies, the novelty of this study is to test the effect of nonlinearity in the concentration of ownership on firm value using 240 non-financial companies listed on the Indonesia Stock Exchange during the period 20102018 with 2,151 observations. The results showed that the concentration of ownership showed the effect of nonlinear U-shaped on firm value. This study confirms that ownership concentration negatively influences the firm's value first and will show a positive effect after reaching a certain point. In addition, the debt level and firm size have a positive effect on the firm's value.
\end{abstract}

Keywords: Firm value, ownership concentration, nonlinear.

\section{ABSTRAK}

Hubungan kepemilikan dan nilai perusahaan masih ada beberapa masalah yang diperdebatkan. Studi sebelumnya hanya meneliti efek linear dari konsentrasi kepemilikan terhadap nilai perusahaan. Penelitian ini dilakukan untuk menguji pengaruh nonlinier dalam konsentrasi kepemilikan terhadap nilai perusahaan menggunakan 240 perusahaan non-keuangan yang terdaftar di Bursa Efek Indonesia selama periode 2010-2018 dengan 2.151 pengamatan. Hasil penelitian menunjukkan bahwa konsentrasi kepemilikan menunjukkan pengaruh berbentuk $U$ (nonlinier) terhadap nilai perusahaan. Penelitian ini menegaskan bahwa konsentrasi kepemilikan memengaruhi secara negatif nilai perusahaan terlebih dahulu dan akan menunjukkan efek positif setelah mencapai titik tertentu. Selain itu, tingkat utang dan ukuran perusahaan memiliki efek positif pada nilai perusahaan. .

Kata kunci : Nilai perusahaan, konsentrasi kepemilikan, nonlinier

\section{INTRODUCTION}

The company is a business entity that runs economic activities intending to obtain profits. If the value of the company increases, it can improve the welfare of its shareholders or owners. Improved company performance can be achieved if the company can increase profits and can maintain its survival. But in the process, there are differences in objectives 
between shareholders and owners, especially in terms of increasing individual achievement and the distribution to be received.

According to agency theory, Jensen and Meckling (1976) explain that the concentration of ownership acts as an internal mechanism to alleviate conflicts between company owners and managers. Agency theory says there is a natural conflict that occurs because of differences in managers and company owners. Agency theory has three assumptions namely moral hazard, risk-averse and bounded rationality. In this highly concentrated environment, conflicts between owners and managers become less important. However, conflicts arise between large and minor shareholders (Renders \& Gaeremynck, 2012).

In companies with concentrated ownership structures, shareholders have high supervisory rights over the company, so agency conflict will be reduced because the management becomes part of the company's activities under the supervision of the shareholders. Therefore the ownership structure as a corporate governance mechanism must be analyzed based on the interests and character of each actor. A concentrated ownership structure has the benefit of an internal mechanism for disciplining management. Ownership of shares owned by the largest shareholder is an incentive to monitor and influence the decision making within the company to act in the interests of shareholders and the company. This cannot be done by shareholders if there is very little share ownership in the company (Shleifer and Vishny, 1986; Shleifer and Vishny, 1997).

Company value is a particular condition that has been achieved by the company to continue his life and be able to maximize profits. Gitman (2006) explains that the purpose of a company that has gone public is to increase the prosperity of the owner or shareholders by increasing the value of the company. High stock prices indicate that the company can provide excellent prospects and provide confidence in the market going forward.

Anderson and Reeb (2003) have found a U-shaped relationship between family ownership and corporate value when companies have a limited ownership structure. As investigated by Lozano et al. (2016) found that if the main owner has effective control over the company (if the ownership of the largest shareholder is large enough to control the control of the company) then the relationship between ownership concentration and firm value is in the form of U. Family companies usually see investment in the long run so they must make the best investment decisions for the company. So this causes family ownership to have a positive effect on company value.

The purpose of this study is to analyze the effect of nonlinear ownership concentration on firm value for companies that have different levels of ownership. Researchers will clarify the effect of ownership on firm value. In this study, researchers used data from the annual financial statements of nonfinancial companies listed on the Indonesia Stock Exchange or IDX in the 2011-2018 periods. 
In Indonesia, several companies have used the concept of ownership to evaluate their company, which is reflected in the annual financial statements. In the study of Lozano et al. (2016) explains that there is a U-shaped relationship between ownership concentration and firm value. The relationship between ownership concentration and firm value, there is a positive relationship for lower ownership levels and has a negative relationship for higher ownership levels.

\section{Agency Theory}

Jensen and Meckling (1976) explain the agency relationship in the agency theory that the company is a collection of contracts (nexus of contracts) between the owners of economic resources (principal) and managers (agents) who take care of the use and control of these resources. Agency relationship causes two problems, namely: the occurrence of asymmetric information (information asymmetry), where management, in general, has more information about the actual financial position and the operating position of the entity of the owner and the occurrence of conflict of interest due to unequal goals, where management does not always act in the interests of the owner. To overcome or reduce this agency problem, agency costs will be borne by both the principal and the agent.

\section{Convergence of Interest}

Jensen and Meckling (1976) state that the convergence of interests between managers and owners can be achieved by giving share ownership to managers. If managers have shares in the company, they will have interests that tend to be the same as other shareholders. With the pooling of interests, agency conflict will be reduced so that managers are motivated to improve firm value and shareholder prosperity.

Managers who have access to company information will have the initiative to manipulate that information if they feel the information is detrimental to their interests. However, if the interests of managers and owners can be aligned, managers will not be motivated to manipulate information or manage earnings so that the quality of accounting information and earnings informatization can improve. Increasing managerial ownership is expected to reduce earnings management actions, as reflected in the reduced value of discretionary accruals. The amount of managerial ownership is expected to improve the quality of financial reporting and the resulting profits.

\section{Entrenchment}

Entrenchment theory is an integrated theory in corporate governance. The entrenchment strategy is carried out by managers to increase personal profitability, the dependency of shareholders and the resources they control in achieving the goal of stabilizing oversight of the company. Entrenchment occurs when there is an increase in expectations by the majority shareholder. 
Majority shareholders have strong control over using the company to fulfill the interests compared to the interests of all shareholders. Entrenchment is the act of controlling shareholders by their control rights to carry out expropriation (Anderson and Reeb, 2003). Entrenchment actions arise due to several things, including the threat of takeover (hostile takeover), compensation received by managers does not match the performance they produce, the number of shares owned by managers is relatively small, and tenure of managers.

\section{Ownership Concentration}

Ogden et al. (2003) define the ownership structure as the distribution of shares among investor classes. Maramis (2007) states that concentrated stock ownership is a condition where most of the shares are owned by a small number of individuals or groups, so that these shareholders have a relatively dominant number of shares, or in other words the concentration of ownership is the largest percentage of ownership owned by an investor, and reveals that the ownership structure in the agency theory literature is divided into two types, namely the structure of concentrated stock ownership and the structure of scattered share ownership. La Porta and Silanez (1999) add that concentrated ownership is a phenomenon commonly found in countries with developing economies such as Indonesia and continental states. Faccio et al. (2000) define that controlling shareholders of a company are major shareholders who have a large percentage of rights, whereas minority shareholders are shareholders who have a small number of shares. Research by Juliardi (2012) and La Porta (1998), states that in Indonesia there is a relatively large concentration of ownership, it is estimated that around 40 to 60 percent of Indonesian company shares are concentrated in the majority shareholder. This concentration of ownership will cause mistrust of the market for the company.

\section{Firm Value}

Brigham and Erdhadt (2005) define that the value of the company is the present value of free cash flow in the future at a discount rate according to the weighted average cost of capital. Free cash flow is cash flow available to investors (creditors and owners) after taking into account all expenses for company operations and expenses for investment and net current assets. Company value according to Gitman (2006), is the actual value per share that will be received if the company's assets sold according to stock prices. Maximizing the value of the company is referred to as maximizing the prosperity of shareholders and maximizing the common stock price of the company. Company value is the investor's perception of the company, which is often associated with stock market prices. Stock market prices indicate the price that investors are willing to pay. 


\section{Size}

Company size is the size of a company. Company size is a scale where companies can be classified into large or small companies, in various ways, including total assets, sales and market capitalization (Sudarmadji and Sularto, 2007). Brigham and Houston (2005) define company size as the average of total net sales for the year to several years. Company size is a characteristic of a company concerning the company structure. The size of the company is measured by the total assets owned by the company. The definition of total assets is all resources controlled by the company as a result of past transactions and are expected to provide economic benefits for the company in the future. Companies that have large assets or are referred to as large companies will get more attention from investors, creditors, the government, and economic analysts compared to small companies.

\section{Leverage}

Debt is capital that originates from loans from banks, financial institutions, or by issuing debt securities, and for this use, the company provides compensation in the form of interest, which is a constant burden for the company. Debt is a company's obligation to pay several money/services/ goods in the future to other parties, due to transactions conducted in the past. Baridwan (2000) classifies debts, including Short-term debt, that is, liability or debt or obligation that must be repaid within one year. There are several types of short-term debt, among others: trade payables (account Payable), notes payable or promissory debt, accrued expenses (accrual liabilities). Long-term debt that is past due, dividend debt, and customer deposit debt. As well as long-term debt, debt that is due more than one year or one accounting period. Maturity can occur in 1.5 years or two years, five years or more. Long-term debt usually arises because of the need for funds to purchase additional fixed assets, increase the amount of permanent working capital, buy another company or maybe also to pay off other debts. Long-Term debt is classified into two groups, namely: mortgage debt, and bond debt.

\section{Return On Asset (ROA)}

Return On Assets is one of the profitability ratios that is intended to measure the ability of the company of the total funds invested in the activities used for the company's operating activities to generate profits by utilizing its assets. ROA shows the ability to manage the capital invested in assets held to generate profits. ROA is an important ratio between existing profitability ratios. Negative ROA is caused by the company's profit in a negative condition or loss. This shows the ability of the invested capital as a whole has not been able to generate profits. Return On Assets is obtained by comparing net income to total assets. Net income is net income after tax. Total Assets are all assets used in activities or businesses to obtain regular income or the company's main business. 


\section{Ownership Concentration and Firm Value}

Jensen and Meckling (1976) state that with large ownership by the manager will further improve the value of the company because there are aligned goals between managers and shareholders, and the conflict that occurs between managers and majority shareholders is reduced because managers also have an investment in the company. Anderson and Reeb (2003), have found an inverse U-shaped relationship between family ownership and corporate value when the company has a limited ownership structure. Whereas the concentration of ownership and value of a company is U-shaped when the major shareholders have effective control over the company. Lozano et al. (2016) have researched the effect of ownership of major shareholders on firm value. The study shows a negative effect on lower levels of ownership when minority shareholders are protected than the opportunity for a lower takeover, therefore, minority shareholders do not need to increase their investment in the company and show positive effects for higher levels of ownership when shareholders are not too protected it will be easier to increase the authority over its ownership but not the authority over the company. Based on the explanation above, it can be concluded that the hypothesis proposed in this study is: There is a nonlinearity effect between ownership concentration and firm value.

This study examines the nonlinearity effect of ownership concentration and firm value. Expect that the effect of variables in the form of U-Shape nonlinearity. Ownership concentration negatively influences the firm's value first and will show a positive effect after reaching a certain point.

\section{METHOD}

The type of data used in this research is secondary data taken from annual reports and financial statements of 240 non-financial sector companies listed on the Indonesia Stock Exchange (IDX) in the period 2010-2018. Data regarding ownership concentration in a company can be obtained from company profile data listed on the Indonesia Stock Exchange (IDX), which can be viewed at www.idx.co.id.

This study uses firm value variables as the dependent variable, ownership concentration as an independent variable and the level of debt and company size as a control variable. Researchers used multiple linear regression to examine the effect of independent variables on the dependent variable with IBM SPSS 25 Statistics for windows as an analysis tool. The technique used to collect data is purposive sampling. That is, elements in the population do not have the same probability of being selected as a sample. In this research, it is necessary to obtain information from specific targets, namely, certain types of people or institutions that will be able to provide the desired information, because the data used must meet specific criteria.

The sample criteria desired by researchers to obtain the relevant results: 
1. The company studied is a non-financial company listed on the Indonesia Stock Exchange (IDX) in 2010-2018 that presents a complete financial and annual report.

2. The company studied has a controlling shareholder value of at least $20 \%$ of the total outstanding shares

Table 1. Sample Selection

\begin{tabular}{lc}
\hline Sample & Total \\
\hline All observation & 2.160 \\
Outlayer (-) & 9 \\
\hline Total observation & $\mathbf{2 . 1 5 1}$ \\
\hline
\end{tabular}

Source: Based on purposive sampling (Author data results in 2010-2018 period)

Table 2. Operational definition dan variables measurement

\begin{tabular}{|c|c|c|}
\hline Variable & & Measurement \\
\hline Firm Value & TOBIN'S Q & $\begin{array}{l}\text { (Market capitalization+total } \\
\text { debt)/total assets }\end{array}$ \\
\hline $\begin{array}{l}\text { Ownership } \\
\text { Concentration }\end{array}$ & $\mathrm{OC}$ & $\begin{array}{l}\text { Total controlling share/total } \\
\text { outstanding share }\end{array}$ \\
\hline Leverage & LEV & Total debt/total assets \\
\hline Firm Size & SIZE & Ln(total assets) \\
\hline Firm Performance & ROA & Net income/total assets \\
\hline
\end{tabular}

Source: Lozano et al. (2016) and Gitman (2006)

Analysis model to determine the effect of ownership concentration on firm value in this study is as follows:

$\operatorname{TOBIN}^{\prime} S Q_{i, t}=\beta_{0}+\beta_{1} O C_{i, t}+\beta_{2} O C_{i, t}^{2}+\beta_{3} L E V_{i, t}+\beta_{4} S I Z E_{i, t}+\beta_{5} R O A_{i, t}+\epsilon_{i, t}$

\section{RESULTS AND DISCUSSIONS}

The description of the study aims to explain the characteristics of each variable studied statistically. The dependent variable used in the study is firm value $(\mathrm{FV})$. The independent variable in this study is ownership concentration (OC). The control variables of this study consisted of company size (SIZE), corporate debt (LEV), and return on assets (ROA). This research description will explain the minimum value, maximum value, mean (average) value, and standard deviation of each variable from observations.

Based on table 1, it can be seen that the average firm value (FV) of the sample companies during the 2010-2018 period was 0.920 . The maximum value and the minimum firm value are 2.668 and 0.409 , respectively. The average company in Indonesia has a concentration of ownership share (OC) of 0.558 . The maximum value of 0.972 indicates the highest share ownership 
in this study sample. The minimum value of 0.254 indicates the lowest share ownership of the company in this study.

Furthermore, the control variable in this study. The average company size (SIZE) is 28,218 . The maximum and minimum values of company size are 32,151 and 23,546. While the average corporate debt (LEV) and Return on Assets (ROA) are 0.462 and 0.046 , respectively. The maximum values are 0.935 and 0.543 . Then the minimum values are 0.003 and -0.436 .

Table 3. Descriptive Statistic

\begin{tabular}{cccccc}
\hline Variable & N & Min. & Max. & Mean & Std. Deviation \\
\hline FV & 2.151 & 0,409 & 2,668 & 0,92027 & 0,373066 \\
OC & 2.151 & 0,254 & 0,972 & 0,55863 & 0,187732 \\
OC2 & 2.151 & 0,065 & 0,945 & 0,34727 & 0,221027 \\
SIZE & 2.151 & 23,546 & 32,151 & 28,21844 & 1,672553 \\
LEV & 2.151 & 0,003 & 0,935 & 0,46231 & 0,193926 \\
ROA & 2.151 & $-0,436$ & 0,543 & 0,04613 & 0,076388 \\
\hline
\end{tabular}

Source: Author data analyst in 2010-2018 period

The following are the results of the analysis and hypothesis testing of multiple linear regression models during the 2010-2018 period. Data processing and analysis of this study used the IBM Statistic 25 for windows.

Table 4. Regression results

\begin{tabular}{|c|c|c|c|c|c|}
\hline \multirow[t]{2}{*}{ Variable } & \multicolumn{2}{|c|}{ Unstandardized Coefficients } & \multirow{2}{*}{$\begin{array}{c}\begin{array}{c}\text { Standardized } \\
\text { Coefficients }\end{array} \\
\text { Beta } \\
\end{array}$} & \multirow[t]{2}{*}{$\mathbf{t}$} & \multirow[t]{2}{*}{ Sig. } \\
\hline & $\boldsymbol{\beta}$ & Std. Error & & & \\
\hline (Constant) & 0,276 & 0,239 & & 1,154 & 0,249 \\
\hline $\mathrm{OC}$ & $-0,844$ & 0,426 & $-0,424$ & $-1,979$ & 0,048 \\
\hline $\mathrm{OC}^{\wedge} 2$ & 1,467 & 0,362 & 0,869 & 4,056 & 0,000 \\
\hline SIZE & 0,015 & 0,008 & 0,068 & 1,962 & 0,050 \\
\hline LEV & 0,275 & 0,070 & 0,143 & 3,940 & 0,000 \\
\hline ROA & 1,061 & 0,175 & 0,217 & 6,047 & 0,000 \\
\hline $\begin{array}{l}\text { R Square } \\
\text { Adj. R Square }\end{array}$ & & & & & $\begin{array}{l}0,268 \\
0,262\end{array}$ \\
\hline Durbin-Watson & & & & & \\
\hline
\end{tabular}

Source: Author data analyst in 2010-2018 period

Based on Table 2 shows that ownership concentration (OC) has a significant negative effect on firm value (FV), and ownership concentration squared $\left(\mathrm{OC}^{\wedge} 2\right)$ has a significant positive effect on firm value. Based on these tests, so it shows that the two variables form a U-shape curve between the concentration of ownership and firm value. Consistent with research by Lozano et al. (2016). The results of the above analysis can be explained with the following Figure 1. 


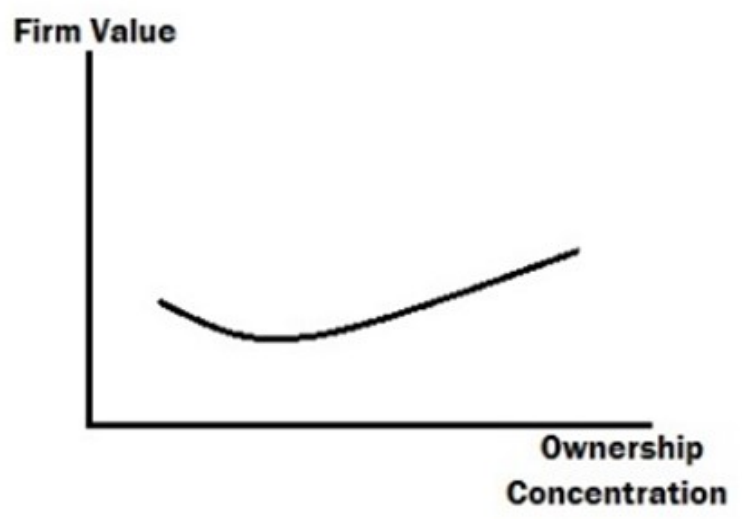

Figure 1. Nonlinear effect of ownership concentration and firm value

From the graphic results of this study, it can be seen that an entrenchment effect occurs when the ownership concentration is low. Shareholders who have a low concentration level tend to think only of their interests and short-term interests but do not consider the value of the company. At present, the agency problem occurs between management and shareholders. Agency conflict between management and shareholders can be minimized by a monitoring mechanism that will cause agency costs. Agency costs incurred by shareholders to oversee management performance become a burden for the company so that it will reduce the profits generated and result in a decline in firm value. Therefore, agency conflict must be minimized by various strategies so that the firm value is high. Agency conflict can occur as a result of asymmetric information between shareholders and managers. As a result, investors are not sure of the company's performance and do not want to buy company shares so that stock prices decline and the value of the company also decreases.

Table 5. Robustness tes with Price Earning Ratio as the dependent variable

\begin{tabular}{|c|c|c|c|c|c|}
\hline \multirow[t]{2}{*}{ Variable } & \multicolumn{2}{|c|}{$\begin{array}{l}\text { Unstandardized } \\
\text { Coefficients }\end{array}$} & \multirow{2}{*}{$\begin{array}{c}\text { Standardized } \\
\text { Coefficients } \\
\text { Beta }\end{array}$} & \multirow[t]{2}{*}{$\mathbf{t}$} & \multirow[t]{2}{*}{ Sig. } \\
\hline & $\beta$ & Std. Error & & & \\
\hline (Constant) & 0,123 & 0,311 & & 1,184 & 0,149 \\
\hline $\mathrm{OC}$ & $-1,232$ & 0,423 & $-0,412$ & $-1,921$ & 0,021 \\
\hline $\mathrm{OC}^{\wedge} 2$ & 2,123 & 0,342 & 0,931 & 4,152 & 0,002 \\
\hline SIZE & 0,121 & 0,022 & 0,098 & 1,989 & 0,012 \\
\hline LEV & 0,333 & 0,090 & 0,198 & 3,980 & 0,001 \\
\hline ROA & 1,865 & 0,178 & 0,411 & 6,655 & 0,000 \\
\hline R Square & & & & & 0,295 \\
\hline Adj. R Square & & & & & 0,292 \\
\hline Durbin-Watson & & & & & 1,106 \\
\hline
\end{tabular}


Table 6. Robustness test with Return on Equity as the dependent variable

\begin{tabular}{|c|c|c|c|c|c|}
\hline \multirow[t]{2}{*}{ Variable } & \multicolumn{2}{|c|}{$\begin{array}{c}\text { Unstandardized } \\
\text { Coefficients }\end{array}$} & \multirow{2}{*}{$\begin{array}{c}\text { Standardized } \\
\text { Coefficients }\end{array}$} & \multirow[t]{2}{*}{$\mathbf{t}$} & \multirow[t]{2}{*}{ Sig. } \\
\hline & $\beta$ & Std. Error & & & \\
\hline (Constant) & 1,232 & 0,332 & & 1,201 & 0,252 \\
\hline $\mathrm{OC}$ & $-1,119$ & 0,471 & $-0,435$ & $-1,981$ & 0,087 \\
\hline $\mathrm{OC}^{\wedge} 2$ & 2,817 & 0,425 & 0,891 & 4,128 & 0,018 \\
\hline SIZE & 0,091 & 0,011 & 0,078 & 1,979 & 0,034 \\
\hline LEV & 0,361 & 0,023 & 0,164 & 3,968 & 0,015 \\
\hline ROA & 1,519 & 0,189 & 0,229 & 6,112 & 0,019 \\
\hline R Square & & & & & 0,319 \\
\hline Adj. R Square & & & & & 0,281 \\
\hline Durbin-Watson & & & & & 1,189 \\
\hline
\end{tabular}

$\mathrm{ROE}=$ Net income/total equity (Gitman, 2006)

Source: Author data analyst in 2010-2018 period

However, at one point, the concentration of ownership increased, resulting in increased company value. This causes a convergence of interest. When the concentration of ownership is higher, the shareholders are more oriented toward thinking about long-term interests by maintaining their investment in the company. Shareholders tend to support management's decision to increase the value of the company, and the majority of shareholders can carry out effective supervision of management performance so that the agency problem is small. Cooperation between shareholders and management in making decisions will affect increasing the value of the company.

Size (company size) has a significant positive effect on firm value, as measured by Tobin's' Q. These results are consistent with research by Barontini \& Caprio (2006). Company size is measured by looking at the overall assets owned by a company. This means that the higher of company's total assets, the better the value of the company. Large companies have more effective control so that an investor responds positively to a company whose book value has large total assets because they can finance the company's operations. With this, the company's value will increase in the capital market. And investors believe that the company will be able to provide large profits.

Leverage (corporate debt) has a significant positive effect on firm value. This shows that the higher the leverage level of a company, the value of the company increases. With a higher level of leverage, the company shows the greater funds provided by creditors (Mamduh and Hanafi, 2007). Leverage can be an external monitoring tool in an effort to achieve the company's goals to maximize the value of the company by reducing the manager's opportunity to act contrary to the interests of shareholders and with a high level of debt can provide better decisions that will increase the company's profitability (Jensen, 1986). During a period of high investment growth, in addition to using internal funding, the company also used external financing in the form of debt. This is done to increase monitoring activities to 
prevent managers from using the company's excess cash (free cash flow) on activities that do not add value to the company or invest excess cash in less profitable investments. This finding supports Mak and Kusnadi (2005) and Davies et al. (2005), which state that financial leverage (debt to total assets) can be used to increase firm value.

Return on Assets (ROA) has a significant positive effect on firm value. This is because the higher the value of ROA means the more efficient use of company assets, so will increase profits (profits) obtained by the company. The relationship between profitability and firm value is based on the signaling theory, if the company can produce a stable and higher profit, then it is seen as a positive signal by investors regarding the company's performance. These results show the positive effect of profitability on firm value. Investors tend to prefer less profitable companies. This is consistent with research conducted by Chen \& Steiner (2000). And according to the study by Iturriaga and Sanz (2001) states that higher profitability (Return on Assets) can increase company value. These results support the signaling theory that underlies the relationship between profitability and firm value.

\section{CONCLUSION}

The study aims to determine the effect of the influence of nonlinearity on ownership concentration on firm value. Based on the test results, analysis, and discussion explained in the previous chapter. This study can be concluded that ownership concentration has a significant negative effect on firm value, and ownership concentration squared has a significant positive effect on firm value of non-financial companies in Indonesia, which is indicated by the nonlinear U curve. Also, based on the results of the study showed that the size (company size), leverage (corporate debt), and Return on Assets (ROA) also have a significant positive effect on the firm value, which indicates the value of the company is increasing.

\section{REFERENCE}

Anderson, R., \& Reeb, D. (2003). Founding-family ownership and firm performance: evidence from the S\&P 500. Journal of Finance, 58, $1301-1328$.

Baridwan, Zaki. (2000). Intermediate Accounting. Edisi Ketujuh, BPFE, Yogyakarta.

Barontini, R., \& Caprio, L. (2006). The effect of family control on firm value and performance: evidence from Continental Europe. European Financial Management, 12, 689-723.

Brigham, Eugene F., and Ehrhardt, Michael C. (2006). Financial Management. (tenth Edition). Orlando: Harcourt College Publishers. 
Chen. Carl. R and Steiner. Thomas. L. (2000). Tobins'Q Managerial Ownership and Analysis Coverage: a non-linear simultaneous equations model. Journal of Economics and Bussiness, 52: 365-382.

Davies, J.R., Hillier, D. \& McColgan, P. (2005). Ownership structure, managerial behavior, and corporate value. Journal of Corporate Finance, 11: 645-660.

Faccio, Mara dan Larry H.P. Lang. (2000). The separation of Ownership and Control: an Analysis of Ultimate Ownership in Western European Corporation. Working Papers.

Gitman, Lawrence J. (2006). Principles of Managerial Finance, seventeenth edition. Massachusetts: Addison-Wesley Publishing Company.

Hanafi, Mamduh M. Dan Abdul Halim. (2007). Analisis Laporan Keuangan. Edisi Ketiga. Yogyakarta: Unit Penerbit dan Percetakan Sekolah Tinggi Ilmu Manajemen YKPN.

Iturriaga, F.J.L. \& Sanz, J.A.R. (2001). Ownership structure, corporate value, and firm investment : a simultaneous equations analysis of spanish companies. Journal of Management and Governance, 5: 179-204.

Jensen, M. C. (1986). Agency Costs of Free Cash Flow, Corporate Finance, and Takeovers. American Economic Review. Vol. 323-329.

Jensen, M., \& Meckling, W. (1976). Theory of the firm: managerial behavior, agency costs and ownership structure. Journal of Financial Economics. Vol. 3, 305-360.

Juliardi, Dodik. (2012). Pengaruh Leverage Konsentrasi Kepemilikan dan Kualitas Auditor Terhadap Nilai dan Perusahaan Persistensi Laba pada Perusahaan Perusahaan Public Industri Manufaktur yang Listed di Bursa Efek Di Indonesia. Surabaya: Pascasarjana Universitas Airlangga.

La Porta, Rafael; Lopez-de-Silanes, Florencio; Shleifer, Andrei; dan Vishny, Robert. (1998). Law dan Finance. Journal of Political Economy. No. 106: 1113-1155.

Lozano, M. B., Martínez, B., \& Pindado, J. (2016). Corporate governance, ownership, and firm value: Drivers of ownership as a good corporate governance mechanism. International Business Review, 25(6), 13331343. 
Mak, Y.T. \& Kusnadi, Y. (2005). Size really matters: further evidence on the negative relationship between board size and firm value. Pacific-Basin Finance Journal, 13: 301-318.

Maramis, Joubert B. (2007). Pengaruh Besaran Perusahaan Terhadap Konsentrasi Kepemilikan Saham, Likuiditas Saham, Free Cash Flow, Diversifikasi Usaha, Leverage dan Nilai Perusahaan Manufaktur yang Go Public di Indonesia. Surabaya: Pascasarjana Universitas Airlangga.

Ogden, Jane. (2003). Some Problems With Social Cognition Models: A Pragmatic and Conceptual Analysis. Health Psychology 22, 424-428.

Renders, A., \& Gaeremynck, A. (2012). Corporate governance, principalprincipal agency conflicts, and firm value in European listed companies. Corporate Governance: An International Review, 20, 125143 .

Shleifer, A., \& Vishny, R. (1986). Large shareholders and corporate control. Journal of Political Economy, 94, 461-488.

Shleifer, A., \& Vishny, R. (1997). A survey of corporate governance. Journal of Finance, 52, 737-783.

Sudarmadji, Adi M \& Sularto, Lana. (2007). Pengaruh Ukuran Perusahaan, Profitabilitas, Leverage dan Tipe kepemilikan Perusahaan terhadap Luas Voluntary Discloure. Laporan Keuangan Tahunan. Proceeding PESAT, Volume 2. 
